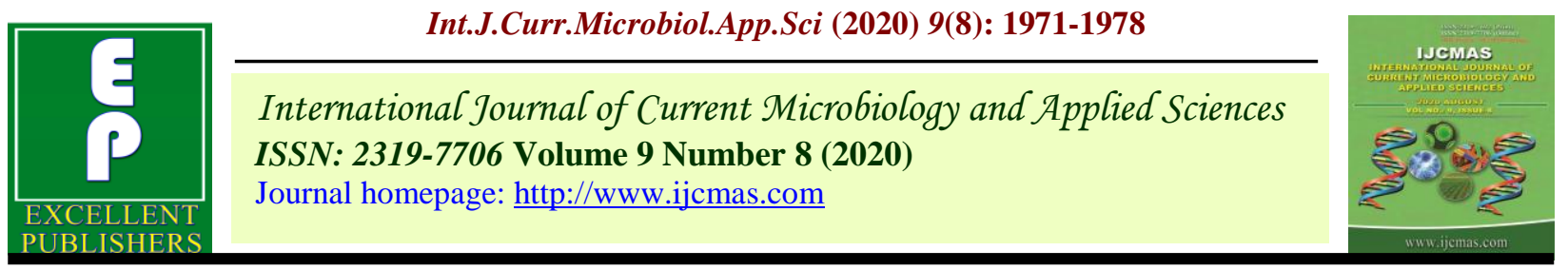

Original Research Article

https://doi.org/10.20546/ijcmas.2020.908.225

\title{
Effect of Soil Test Crop Response based Manure and Fertilizer Application on Potassium Fractions in Soil Inceptisol
}

\author{
V. R. Mageshen*, R. Jayaraghavi, V.S.V.G. Naresh and N. Sathiya Bama \\ Department of Soil Science and Agricultural Chemistry, Pandit Jawaharal Nehru College of \\ Agriculture and Research Institute, Karaikal, Puducherry, India \\ *Corresponding author
}

Keywords

Incubation, STCR-

IPNS, Potassium

fractions, FYM,

Lower, Integrated

Article Info

Accepted:

18 July 2020

Available Online:

10 August 2020

\section{A B S T R A C T}

An incubation experiment was conducted to study the combined effect of various fertilizer doses and Soil Test Crop Response (STCR) based Integrated Plant Nutrient System (IPNS) on potassium (K) fractions in bahour soil series of puducherry. The incubation experiment was carried out with ten treatments and three replications. The soil samples were drawn at $0^{\text {th }}, 40^{\text {th }}$ and $80^{\text {th }}$ day of incubation and subjected for analysis of Water Soluble K, Exchangeable K, and Non Exchangeable $\mathrm{K}$ fractions. The results revealed that the application of STCR + IPNS - $180 \mathrm{q} \mathrm{ha}^{-1}$ treatment has improved the activities of Water Soluble K (30.57 mg kg $\mathrm{mg}^{-1}$ ) and Exchangeable $\mathrm{K}$ (146.43 $\mathrm{mg} \mathrm{kg}^{-1}$ ) and application of Farm Yard Manure $\left(12.5 \mathrm{t} \mathrm{ha}^{-1}\right)$ alone increased the activity of Non exchangeable $\mathrm{K}$ $\left(381.50 \mathrm{mg} \mathrm{kg}^{-1}\right)$. The simple regression analysis proved that the rate of release was higher in STCR + IPNS treatments for water soluble and exchangeable K whereas it was lower for non exchangeable K. Hence it can be concluded the integrated use of STCR based NPK fertilizer along with IPNS increased the available potassium fractions in soil.

\section{Introduction}

Potassium is one of the most important primary nutrients which is required by plants in large quantities and has several physiological functions within the plant. There are four forms of $\mathrm{K}$ in the soils: solution $\mathrm{K}$, exchangeable $\mathrm{K}$, fixed $\mathrm{K}$ or non exchangeable $\mathrm{K}$ and mineral $\mathrm{K}$. The kinetic and equilibrium reactions between the four forms of soil $\mathrm{K}$ affect the level of $\mathrm{K}$ in soil solution and readily available forms for plant uptake at any particular time. The four forms of $\mathrm{K}$ in the order of their availability to microbes and plants are solution > exchangeable > fixed > mineral K (Sparks and Huang, 1985; Sparks, 1987; Sparks 2000). As regards the distribution of $K$ in 
different forms, the solution and exchangeable $\mathrm{K}$ are easily available for crop uptake and non exchangeable $\mathrm{K}$ is relatively less available, but can be made available by the processes which induce the release of $\mathrm{K}$ from the specific sites of $\mathrm{K}$ fixation on the clay complex.

Soil solution $\mathrm{K}$ or water soluble $\mathrm{K}$ is the form readily available for microbial and plant uptake. The levels of soil solution $\mathrm{K}$ generally are low unless a recent application of a $\mathrm{K}$ fertilizer has been made. Solution K levels are affected by equilibrium and kinetic reactions that occur between the forms of soil K, soil moisture content, concentrations of divalent cations in solution and exchange phase (Sparks, 2000). The exchangeable $\mathrm{K}$ is readily available to plants, exchangeable with other cations present in clay minerals and humic substances. These adsorption sites can be planes or edge position of clay minerals or the negative charges created by carboxylic and phenolic groups of humus colloids compared to $\mathrm{pH}$ dependent negative charges on clay (Kirkman et al., 1994). Exchangeable $\mathrm{K}$ is held by the negative charges of organic matter and clay minerals. Potassium in wedge, edge, cracks and step positions is regarded as fixed $\mathrm{K}$. The amount of fixation depends on the quantity and type of clay, and removal of $\mathrm{K}$ from minerals.

The amount of each $\mathrm{K}$ fraction varies, depending on cropping history, as well as chemical fertilizer or organic manure application. In some soils, non-exchangeable $\mathrm{K}$ becomes available as the exchangeable and solution $\mathrm{K}$ are removed by cropping or lost by leaching. In other soils, release from nonexchangeable $\mathrm{K}$ is slow to meet crop requirement. When there is surplus $\mathrm{K}$ in the soil solution (by the addition of fertilizer), the element is transferred to the exchangeable and non-exchangeable fractions through exchange and fixation process (Akinrinde, 2006). .
Potassium being a mobile element in plants, behaves differently in soil and rarely a dynamic equilibrium is observed in soil. There is also very little information is available on the $\mathrm{K}$ management involving organic and inorganic sources. Keeping all these things in mind, present study was emphasised on potassium fractions under controlled conditions.

\section{Materials and Methods}

\section{Laboratory experiment}

The incubation experiment was conducted at Pandit Jawaharlal Nehru College of Agriculture and Research Institute, PAJANCOA \& RI, Karaikal in 2018 . The study was taken up on a inceptisol soil belongs to Bahour soil series, classified as fine, mixed isohyperthermic, Typic Ustropept. The treatments allocated were $\mathrm{T}_{1}$-Control, $\mathrm{T}_{2}$ FYM alone@12.5 t ha $^{-1}, \mathrm{~T}_{3^{-}}$blanket recommendation, $\mathrm{T}_{4}$ - farmer's practice , $\mathrm{T}_{5^{-}}$ STCR-NPK alone @ $160 \mathrm{q} \mathrm{ha}^{-1}$ yield target, $\mathrm{T}_{6}$ - STCR-NPK alone @ $170 \mathrm{q} \mathrm{ha}^{-1}$ yield target, $\mathrm{T}_{7}$ - STCR-NPK alone @180 q ha ${ }^{-1}$ yield target, $\mathrm{T}_{8}$ STCR-IPNS @ $160 \mathrm{q} \mathrm{ha}^{-1}$ yield target, $\mathrm{T}_{9}-$ STCR-IPNS @ $170 \mathrm{q} \mathrm{ha}^{-1}$ yield target, $\mathrm{T}_{10}-\mathrm{STCR}$ - IPNS @ $180 \mathrm{q} \mathrm{ha}^{-1}$ yield target. The treatments were replicated three times in complete randomized design (CRD). The soil used for incubation was neutral in $\mathrm{pH}$ and low in salt content. The soil was low in organic carbon. The available N,P and $\mathrm{K}$ status were low, medium and medium respectively.

\section{Soil sample collection}

Soil samples collected were air-dried and sieved through a 2-mm sieve. A sample of $500 \mathrm{~g}$ of soil was weighed into plastic cups with tight lids. The soil was thoroughly mixed with different rates of organic and inorganic fertilizers and brought to field capacity with 
deionized water. The plastic cups were left in the laboratory at room temperature $\left(25^{\circ} \mathrm{C}\right)$. To enhance the rate of decomposition, the soil was stirred once daily with a glass rod and left opened for $2 \mathrm{~h}$ to allow the release of $\mathrm{CO}_{2}$ as to reduce $\mathrm{CO}_{2}$ stress on microbial activities. The soil samples were drawn at 0, 40 and 80 days of incubation, processes and subjected to potassium fractionation viz., Water soluble $\mathrm{K}$ (Narayanan Nambiar, 1972), Exchangeable K (Pratt, 1965) and Non Exchangeable K (Wood and De turk, 1940).

\section{Potassium fractionation}

\section{Water soluble potassium}

Ten gram of soil sample was transferred to a centrifuge tube and $25 \mathrm{ml}$ of distilled water was added. The tube was shaken for 10 minutes, centrifuged and the clear supernatant liquid was filtered. The filtrate was collected in $100 \mathrm{ml}$ volumetric flask. Three additional extractions were made in the same manner and the combined extract diluted to $100 \mathrm{ml}$ with distilled water. The extract thus obtained was mixed well and potassium determined by using flame photometer (Narayanan Nambiar, 1972).

\section{Exchangeable potassium}

The method of Pratt (1965) was followed. A $10 \mathrm{~g}$ of soil sample was transferred to a $50 \mathrm{ml}$ centrifuge tube and $25 \mathrm{ml}$ of neutral normal ammonium acetate was added to the tube. The tube was shaken for 10 minutes, centrifuged and the clear supernatant liquid filtered. The filtrate was collected in a $100 \mathrm{ml}$ volumetric flask. Three additional extractions were made in the same manner and the combined extracts diluted to $100 \mathrm{ml}$ with neutral normal ammonium acetate. The solution was mixed well and $\mathrm{K}$ estimated using flame photometer. The difference between water soluble and the ammonium acetate extractable $\mathrm{K}$ was computed as the exchangeable K.

\section{Non exchangeable potassium}

Normal nitric acid $\left(\mathrm{HNO}_{3}\right)$ extractable potassium was determined by employing the method of Wood and De Turk (1940). A $2.5 \mathrm{~g}$ finely ground soil sample was transferred to a $100 \mathrm{ml}$ conical flack and $25 \mathrm{ml}$ of normal nitric acid was added. The flask was then heated over a gas burner and the content was made to boil gently for 10 minutes. The content was then cooled, diluted, filtered and the filtrate was collected in a $100 \mathrm{ml}$ volumetric flask. The soil residue was then washed four times with $15 \mathrm{ml}$ portions of $0.1 \mathrm{NHNO}_{3}$ and collected in the same volumetric flask, mixed thoroughly and $\mathrm{K}$ determined using flame photometer. The difference between the normal nitric acid extractable $\mathrm{K}$ and water soluble plus exchangeable $\mathrm{K}$ was taken as nonexchangeable $\mathrm{K}$.

\section{Statistical analysis}

The data on potassium fractions were subjected to statistical scrutiny following the procedure outlined by Gomez and Gomez (1976). A simple linear regression analysis was performed to know release pattern of potassium under different treatments.

\section{Results and Discussion}

\section{Water soluble-K}

Data on the effects of organic and inorganic source on water soluble $\mathrm{K}$ at different days of incubation is presented in Table 1. The highest water soluble $\mathrm{K}\left(30.57 \mathrm{mg} \mathrm{kg}^{-1}\right)$ was recorded in STCR+IPNS-180 q ha ${ }^{-1}$ treatment followed by STCR+IPNS-170 q ha ${ }^{-1}$ (28.84 $\mathrm{mg} \mathrm{kg}^{-1}$ ) which was comparable with STCRNPK alone and blanket recommendation treatments. The lowest water soluble K (23.38 $\mathrm{mg} \mathrm{kg}^{-1}$ ) was recorded in control. The highest water soluble $\mathrm{K}$ was recorded at $80^{\text {th }}$ day of incubation followed by $40^{\text {th }}$ day of incubation 
which were on par with each other. The interaction effect between treatments and days was significant and further revealed that the highest amount of water soluble $\mathrm{K}$ was noticed in STCR + IPNS - $180 \mathrm{q} \mathrm{ha}^{-1}$ treatment at $80^{\text {th }}$ day of incubation. The change in the water soluble $\mathrm{K}$ was found to be - $0.023 \mathrm{mg} \mathrm{kg}^{-1} \mathrm{day}^{-1}$ in control as compared to $0.148 \mathrm{mg} \mathrm{kg}^{-1}$ day $^{-1}$ in STCR+IPNS- $180 \mathrm{q}$ $\mathrm{ha}^{-1}$ Table 4 . The rate of release of water soluble $\mathrm{K}$ was found to be non significant in STCR-NPK alone, farmer's practice and control treatments, whereas it was significantly predicted in STCR+IPNS-180 q $\mathrm{ha}^{-1}$ treatment $\left(\mathrm{R}^{2}=0.928 * *\right)$ with a rate of release of $0.148 \mathrm{mg} \mathrm{kg}^{-1}$ day $^{-1}$

In the present investigation, the highest water soluble $\mathrm{K}$ content was recorded in STCR+IPNS treatments. Except in organic manure added treatments all the other treatments had registered higher water soluble $\mathrm{K}$ upto $40^{\text {th }}$ day of incubation thereafter it decreased. This might be due to the fixation of $\mathrm{K}$ on non exchangeable sites as there is an increase in $\mathrm{K}^{+}$ions in the solution.

The excess of $\mathrm{K}^{+}$ions in solution get exchanged with other cations and get fixed on exchangeable and non exchangeable sites. The increase in water soluble $\mathrm{K}$ in STCRIPNS treatment shows the release of $\mathrm{K}$ from the added $\mathrm{K}$ and also from the organic and native source and also due to the favourable influence of FYM on soil properties. The simple linear regression analysis revealed that the water soluble $\mathrm{K}$ content of the soil was significantly predicted in STCR-IPNS treatment $\left(\mathrm{R}^{2}=0.928^{* *}\right)$ further confirmed the above result.

\section{Exchangeable-K}

The highest amount of exchangeable $\mathrm{K}$ content was registered in STCR + IPNS - 180 $\mathrm{q} \mathrm{ha}^{-1}$ treatment $\left(146.43 \mathrm{mg} \mathrm{kg}^{-1}\right)$ which was significantly different from all the other treatments Table 2. Among the treatments FYM (12.5 $\mathrm{t} \mathrm{ha}^{-1}$ ) alone treatment recorded lowest amount (127.87 mg $\left.\mathrm{kg}^{-1}\right)$ of exchangeable $\mathrm{K}$ content, and was comparable with farmer's practice $\left(131.60 \mathrm{mg} \mathrm{kg}^{-1}\right)$. The highest Exchangeable $\mathrm{K}$ content was recorded at $80^{\text {th }}$ day of incubation (138.81 $\mathrm{mg} \mathrm{kg}^{-1}$ ) which was significantly different from all the other days but the $0^{\text {th }}$ day and $40^{\text {th }}$ day of incubation were on par with each other. The interaction effect further revealed that the highest amount of exchangeable $\mathrm{K}$ was noticed in STCR + IPNS - $180 \mathrm{q} \mathrm{ha}^{-1}$ treatment at $80^{\text {th }}$ day of incubation followed by other STCR + IPNS treatments. The change in exchangeable $\mathrm{K}$ content was quantified using simple regression analysis Table 4. It was found to be significantly explained in STCR + IPNS and blanket recommendation treatments by the days of incubation. It was noticed that in STCR + IPNS- $180 \mathrm{q} \mathrm{ha}^{-1}$ treatment the rate of release was $0.266 \mathrm{mg} \mathrm{kg}^{-1} \mathrm{day}^{-1}$ as compared to 0.031 $\mathrm{mg} \mathrm{kg}^{-1} \mathrm{day}^{-1}$ in blanket recommendation. It was also worth mentioning that the rate of release was lower with the application of STCR-NPK alone than when they were applied with organics.

Application of organic manure along with STCR and blanket recommendation had registered higher exchangeable $\mathrm{K}$ content and the release was increased upto $80^{\text {th }}$ day of incubation. This might be due to the fact that the addition of FYM could increase the CEC of the soil, which can hold more exchangeable $\mathrm{K}$ and convert $\mathrm{K}$ from non exchangeable $\mathrm{K}$ form to exchangeable $\mathrm{K}$ form (Kirkman et al., 1994). The integrated use of organic manures with the inorganic fertilizes have resulted in an increase in the water soluble and exchangeable $\mathrm{K}$, it might be due to the release of organic acids during decomposition of organic manure, which dissolves the $\mathrm{K}$ present in mineral form (or) in the non exchangeable form (Swetha, 2015). 
Table.1 Effect of different fertilizer doses of NPK and STCR - IPNS on Water Soluble- K (mg kg-1)

\begin{tabular}{|c|c|c|c|c|}
\hline Treatments & $0^{\text {th }}$ day & $40^{\text {th }}$ day & $80^{\text {th }}$ day & $\begin{array}{c}\text { Treatment } \\
\text { Mean }\end{array}$ \\
\hline $\mathbf{T}_{1}$-Control & 24.20 & 23.62 & 22.32 & 23.38 \\
\hline $\mathrm{T}_{2^{-}}$FYM (12.5 $\left.\mathrm{t} \mathrm{ha}^{-1}\right)$ alone & 25.26 & 19.32 & 26.20 & 23.59 \\
\hline $\mathrm{T}_{3}$-Farmer's Practice & 27.03 & 22.06 & 24.62 & 24.57 \\
\hline $\mathbf{T}_{4}$-Blanket Recommendation & 26.04 & 23.62 & 28.10 & 25.92 \\
\hline $\mathrm{T}_{5}$-STCR-NPK alone-160 q $\mathrm{ha}^{-1}$ & 25.20 & 28.62 & 21.62 & 25.14 \\
\hline$T_{6}$-STCR-NPK alone-170 q ha $^{-1}$ & 25.32 & 30.62 & 22.56 & 26.16 \\
\hline T $_{7}$-STCR-NPK alone-180 q ha ${ }^{-1}$ & 25.44 & 32.22 & 23.86 & 27.17 \\
\hline $\mathrm{T}_{8}-\mathrm{STCR}+\mathrm{IPNS}-160 \mathrm{q} \mathrm{ha}^{-1}$ & 24.75 & 26.12 & 29.52 & 26.79 \\
\hline 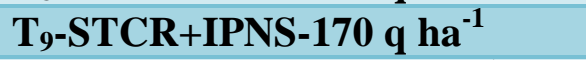 & 24.44 & 28.62 & 33.46 & 28.84 \\
\hline $\mathrm{T}_{10}$-STCR+IPNS-180 q $\mathrm{ha}^{-1}$ & 24.97 & 29.88 & 36.86 & 30.57 \\
\hline Days Mean & 25.26 & 26.47 & 26.91 & \\
\hline
\end{tabular}

\begin{tabular}{|l|l|l|l|}
\hline & T & D & T X D \\
\hline S.Ed & 1.70 & 0.90 & 3.00 \\
\hline C.D(0.05) & 3.40 & 1.90 & NS \\
\hline
\end{tabular}

Table.2 Effect of different fertilizer doses of NPK and STCR - IPNS on Exchangeable- $\mathrm{K}\left(\mathrm{mg} \mathrm{kg}^{-1}\right)$

\begin{tabular}{|c|c|c|c|c|}
\hline Treatments & $0^{\text {th }}$ day & $40^{\text {th }}$ day & $80^{\text {th }}$ day & Treatment Mean \\
\hline$T_{1}$-Control & 132.52 & 131.60 & 130.52 & 131.54 \\
\hline $\mathrm{T}_{2}-\mathrm{FYM}\left(12.5 \mathrm{t} \mathrm{ha}^{-1}\right)$ alone & 134.56 & 120.62 & 128.44 & 127.87 \\
\hline$T_{3}$-Farmer's Practice & 135.60 & 128.60 & 130.62 & 131.60 \\
\hline $\mathbf{T}_{4}$-Blanket Recommendation & 136.62 & 132.20 & 139.12 & 135.98 \\
\hline $\mathrm{T}_{5}$-STCR-NPK alone-160 q $\mathrm{ha}^{-1}$ & 135.60 & 139.42 & 131.60 & 135.54 \\
\hline $\mathrm{T}_{6}$-STCR-NPK alone-170 q $\mathrm{ha}^{-1}$ & 137.00 & 144.60 & 135.60 & 139.06 \\
\hline $\mathrm{T}_{7}$-STCR-NPK alone-180 q $\mathrm{ha}^{-1}$ & 136.86 & 148.80 & 137.12 & 140.92 \\
\hline $\mathrm{T}_{8}-\mathrm{STCR}+\mathrm{IPNS}-160 \mathrm{q} \mathrm{ha}^{-1}$ & 132.52 & 135.60 & 145.60 & 137.90 \\
\hline T9-STCR+IPNS-170 q ha he $^{-1}$ & 135.60 & 140.32 & 151.22 & 142.38 \\
\hline$T_{10}-S T C R+I P N S-180 q \mathrm{ha}^{-1}$ & 137.02 & 143.96 & 158.32 & 146.43 \\
\hline Days Mean & 135.39 & 136.57 & 138.81 & \\
\hline
\end{tabular}

\begin{tabular}{|l|l|l|l|}
\hline & T & D & T X D \\
\hline S.Ed & 0.62 & 0.34 & 1.08 \\
\hline C.D(0.05) & 1.25 & 0.68 & 2.16 \\
\hline
\end{tabular}


Table.3 Effect of different fertilizer doses of NPK and STCR - IPNS on Non Exchangeable- K (mg kg-1)

\begin{tabular}{|c|c|c|c|c|}
\hline Treatments & $0^{\text {th }}$ day & $40^{\text {th }}$ day & $80^{\text {th }}$ day & Treatment Mean \\
\hline $\mathbf{T}_{1}$-Control & 367.60 & 364.96 & 365.76 & 366.10 \\
\hline $\mathrm{T}_{2-}$ FYM (12.5 $\left.\mathrm{t} \mathrm{ha}^{-1}\right)$ alone & 360.78 & 406.26 & 377.48 & 381.50 \\
\hline$T_{3}$-Farmer's Practice & 360.09 & 379.96 & 370.88 & 370.31 \\
\hline $\mathbf{T}_{4}$-Blanket Recommendation & 361.70 & 372.84 & 348.00 & 360.84 \\
\hline $\mathrm{T}_{5}$-STCR-NPK alone-160 q $\mathrm{ha}^{-1}$ & 359.82 & 340.58 & 365.44 & 355.28 \\
\hline $\mathrm{T}_{6}$-STCR-NPK alone-170 q ha $\mathrm{ha}^{-1}$ & 364.56 & 329.18 & 365.66 & 353.13 \\
\hline $\mathrm{T}_{7-S T C R-N P K}$ alone-180 q $\mathrm{ha}^{-1}$ & 360.36 & 319.20 & 367.68 & 349.08 \\
\hline $\mathrm{T}_{8}$-STCR+IPNS-160 q $\mathrm{ha}^{-1}$ & 363.51 & 374.40 & 330.00 & 355.97 \\
\hline T9-STCR+IPNS-170 q ha $^{-1}$ & 364.94 & 372.74 & 315.34 & 351.00 \\
\hline 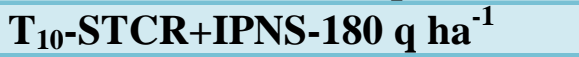 & 358.67 & 373.38 & 301.14 & 344.39 \\
\hline Days Mean & 362.20 & 363.35 & 350.73 & \\
\hline
\end{tabular}

\begin{tabular}{|l|l|l|l|}
\hline & T & D & T X D \\
\hline S.Ed & 8.59 & 4.70 & 14.88 \\
\hline C.D(0.05) & 17.20 & 9.42 & 29.80 \\
\hline
\end{tabular}

Table.4 Results of simple regression analysis between potassium fractions (Y) and days of incubation $(\mathrm{X})$

\begin{tabular}{|c|c|c|c|c|c|c|c|c|c|}
\hline \multirow[b]{2}{*}{ Treatments } & \multicolumn{3}{|c|}{ Water soluble K } & \multicolumn{3}{|c|}{ Exchangeable $\mathrm{K}$} & \multicolumn{3}{|c|}{ Non Exchangeable K } \\
\hline & $\mathbf{R}^{2}$ & Intercept & $\begin{array}{c}\text { Changes } \\
\text { per day } \\
\left(\mathrm{mg} \mathrm{kg}^{-1}\right. \\
\left.\text { day }^{-1}\right)\end{array}$ & $\mathbf{R}^{2}$ & Intercept & $\begin{array}{c}\text { Changes } \\
\text { per day } \\
\left(\mathrm{mg} \mathrm{kg}^{-1}\right. \\
\left.\text { day }^{-1}\right)\end{array}$ & $\mathbf{R}^{2}$ & Intercept & $\begin{array}{c}\text { Changes } \\
\text { per day } \\
\left(\mathrm{mg} \mathrm{kg}^{-1}\right. \\
\left.\text { day }^{-1}\right)\end{array}$ \\
\hline $\mathrm{T}_{1}$-Control & $0.385^{\mathrm{NS}}$ & 24.32 & -0.023 & $0.060^{\mathrm{NS}}$ & 132.54 & -0.025 & $0.003^{\mathrm{NS}}$ & 367.02 & 0.023 \\
\hline $\begin{array}{l}\mathrm{T}_{2^{-}} \text {FYM }\left(12.5 \mathrm{t} \mathrm{ha}^{-}\right. \\
\left.1^{\prime}\right) \text { alone }\end{array}$ & $0.614 *$ & 23.12 & 0.011 & $0.147^{\mathrm{NS}}$ & 130.93 & -0.076 & $0.077^{\mathrm{NS}}$ & 373.15 & 0.208 \\
\hline $\begin{array}{l}\mathbf{T}_{3} \text {-Farmer's } \\
\text { Practice }\end{array}$ & $0.188^{\mathrm{NS}}$ & 25.77 & -0.030 & $0.216^{\mathrm{NS}}$ & 134.09 & -0.062 & $0.065^{\mathrm{NS}}$ & 364.91 & -0.134 \\
\hline $\begin{array}{l}\mathbf{T}_{4} \text {-Blanket } \\
\text { Recommendation }\end{array}$ & $0.657 *$ & 24.89 & 0.025 & $0.554 *$ & 134.73 & 0.031 & $0.397 *$ & 367.69 & -0.371 \\
\hline $\begin{array}{l}\mathrm{T}_{5} \text {-STCR-NPK } \\
\text { alone-160 q ha }\end{array}$ & $0.265^{\mathrm{NS}}$ & 27.02 & -0.051 & $0.125^{\text {NS }}$ & 137.54 & -0.050 & $0.016^{\mathrm{NS}}$ & 352.47 & 0.070 \\
\hline $\begin{array}{l}\text { T}_{6}-\mathrm{STCR}-\mathrm{NPK} \\
\text { alone-170 q ha } \\
\end{array}$ & $0.102^{\mathrm{NS}}$ & 27.54 & -0.034 & $0.011^{\mathrm{NS}}$ & 139.76 & -0.017 & $0.0004^{\mathrm{NS}}$ & 352.58 & 0.083 \\
\hline $\begin{array}{l}\text { T}_{7} \text {-STCR-NPK } \\
\text { alone-180 q ha }\end{array}$ & $0.001^{\mathrm{NS}}$ & 26.90 & -0.004 & $\underset{\text { NS }}{0.0003}$ & 140.79 & 0.003 & $0.013^{\mathrm{NS}}$ & 345.42 & 0.091 \\
\hline $\begin{array}{l}\text { T}_{8} \text {-STCR+IPNS-160 } \\
\text { q ha }{ }^{-1}\end{array}$ & $0.725 * *$ & 24.41 & 0.059 & $0.669 * *$ & 131.36 & 0.163 & $0.429 *$ & 372.72 & -0.418 \\
\hline 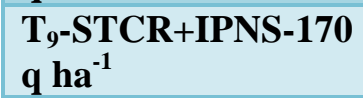 & $0.904 * *$ & 24.33 & 0.112 & $0.739 * *$ & 134.57 & 0.195 & $0.483^{*}$ & 375.69 & -0.500 \\
\hline $\begin{array}{l}\text { T}_{10} \text {-STCR+IPNS- } \\
180 \mathrm{q} \mathrm{ha}^{-1}\end{array}$ & $0.928 * *$ & 24.62 & 0.148 & $0.825^{* *}$ & 135.78 & 0.266 & $0.472 *$ & 373.23 & -0.720 \\
\hline
\end{tabular}




\section{Non exchangeable-K}

The results indicated that the highest non exchangeable $\mathrm{K}$ content was recorded in FYM $\left(12.5 \mathrm{t} \mathrm{ha}^{-1}\right)$ alone treatment $(381.50 \mathrm{mg}$ $\left.\mathrm{kg}^{-1}\right)$ followed by farmer's practice (370.31 $\mathrm{mg} \mathrm{kg}^{-1}$ ) and control treatments $(366.10 \mathrm{mg}$ $\left.\mathrm{kg}^{-1}\right)$. At $40^{\text {th }}$ day of incubation the highest non exchangeable $\mathrm{K}$ content was observed followed by $0^{\text {th }}$ day of incubation which were on par with each other Table 3. The interaction effect further revealed that the highest amount of non exchangeable $\mathrm{K}$ was noticed in FYM $\left(12.5 \mathrm{t} \mathrm{ha}^{-1}\right)$ alone treatment at $40^{\text {th }}$ day of incubation and the lowest being recorded in STCR + IPNS treatments. The rate of decrease in non exchangeable $\mathrm{K}$ content was quantified using simple regression analysis which revealed that in STCR+IPNS and blanket recommendation treatments, the significant change in non exchangeable $\mathrm{K}$ content could be attributed to the number of days of incubation Table 4 . The rate of decrease was found to be maximum in the case of STCR + IPNS - $180 \mathrm{q} \mathrm{ha}^{-1}$ ($\left.0.720 \mathrm{mg} \mathrm{kg}^{-1} \mathrm{day}^{-1}\right)$ and the least was in control $\left(0.023 \mathrm{mg} \mathrm{kg}^{-1}\right.$ day $\left.^{-1}\right)$. It was further noticed that when organic manure was applied along with STCR there was sharp increase in the rate of decrease as compared to STCR-NPK alone

Application of organic manures increased the non exchangeable $\mathrm{K}$ upto $40 \mathrm{DAI}$ and decreased at $80^{\text {th }}$ day. The decrease in the non-exchangeable $\mathrm{K}$ at $80^{\text {th }}$ day in the treatments receiving either the organic manures or the STCR+IPNS practices could be due to the formation of organo metallo complexes of higher solubility. The corresponding increase in easily available forms of $\mathrm{K}$ appears to have resulted from their translocation from non-exchangeable to easily soluble forms. This could be clearly visible with a significant decrease in the nonexchangeable $\mathrm{K}$ and a corresponding increase in water soluble and exchangeable $\mathrm{K}$ in these treatments. The greater depletion of non exchangeable $\mathrm{K}$ in the presence of organic matter might be due to the shift in CEC sites towards divalent selectivity (Salmon, 1964) which would decrease percentage $\mathrm{K}$ saturation of CEC resulting in the shift of equilibrium of non exchangeable $\mathrm{K}$ to exchangeable K (Majumdar et al., 2002).

In conclusion, the application of STCR+IPNS treatment increased the content of water soluble $\mathrm{K}$ and exchangeable $\mathrm{K}$ fractions and decrease the non exchangeable $\mathrm{K}$ content. The organic acids released as a result of decomposition of organic manures help in the conversion of the non-exchangeable forms of $\mathrm{K}$ to available forms of $\mathrm{K}$. However, organic manures alone cannot meet the nutrient requirements as they contain small amounts of essential nutrients and get released slowly during decomposition, thus nutrients requirement of the crop when needed is not fulfilled. Hence a blend of organic manures and inorganic fertilizers ensures the immediate supply of the nutrients from inorganic fertilizers in the initial stages and from the decomposition of organic manures to cater to the nutrient needs at the later stages of crop growth.

\section{References}

Akinrinde, O. O. 2006. Strategies for improving crop's use- efficiencies of fertilizer nutrients in sustainable agricultural systems. Pakistan Journal of Nutrition5 (2):185-93.

Gomez, A.A. and R.A. Gomez. 1976. Statistical procedure for agricultural research with emphasis on rice. IARI. Los Banos, Manila, Philippines. pp. 294.

Kirkman, J.H., A. Baskar, A. Srapaneni, A.N. Macgregor. 1994. Potassium in the soils of New Zealand. New Zealand J. of 
Agric. Res. 37: 207-227.

Majumdar, B., M.S. Venkatesh, Kailash Kumar and Patiram. 2002. Effect of levels of potassium and FYM on yield and uptake of nutrients by sweet potato and different forms of $\mathrm{K}$ in an acidic Alfisol of Meghalaya. J. Potash Res., 18: 84-89.

Narayan Nambiar, P.K. 1972. Studies on soil potassium. Ph.D., Thesis. Tamil Nadu Agricultural University, Coimbatore, India.

Pratt, P.E. 1965. Potassium. In Methods of Soil Analysis. C.A. Black (ed). Part 2. Agronomy 9, Amer. Soc. of Agron., Madison, Wis., pp. $1022-1030$.

Salmon. 1964. Cation exchange reactions. J. Soil Sci, 15: 273-283.

Sparks, D.L. 1987. Potassium dynamics in soils. Adv. Soil Sci. 6:1-63.
Sparks, D.L. 2000. Bioavailability of soil potassium. In M.E. Sumner (ed.) Handbook of soil science, CRC Press, Boca Raton, FL. pp. 38-52

Sparks, D. L., and P.M. Huang. 1985. Physical chemistry of soil potassium. In Munson, R. D. (ed.). Potassium in agriculture. SSSA, Madison, WI. pp. 201-276.

Swetha, L. 2015. Integrated nutrient management in bhendi (Abelmoschus esculentus L.) with special reference to potassium. M.sc thesis. PJTSAU, Hyderabad, India.

Wood, L.K. and E.E. De Turk. 1940. Adsorption of ammonium and potassium in non- replaceable forms. Pro. Soil Sci. Soc. Am., 5: 152 - 161.

\section{How to cite this article:}

Mageshen, V. R., R. Jayaraghavi, V.S.V.G. Naresh and Sathiya Bama, N. 2020. Effect of Soil Test Crop Response based Manure and Fertilizer Application on Potassium Fractions in Soil Inceptisol. Int.J.Curr.Microbiol.App.Sci. 9(08): 1971-1978.

doi: https://doi.org/10.20546/ijcmas.2020.908.225 